\title{
Short films in Canada
}

By Patricia Thompson

Spring 1996 Issue of KINEMA

(1) SPEAKING OF MOVIES

Director: Michael Ostroff.

Narrator: Laurie Lapierre.

Canada 1994, 24 min.

Pioneer filmmaker Gordon Sparling speaks out the title -- he was over 90 then and, like much of Canadian film history, long forgotten. This little documentary gives a brief glimpse of Sparling's talents, and whets the appetite for more of the lively and punchy "shorts" he made as head of production at Associated Screen News in Montréal from 1930-1954. These ten-minute theatrical entertainments were shot inexpensively and covered many subjects, with music, drama and humour abounding, and in the 1930's were being produced at the rate of one a month.

Among the tiny excerpts in this film, Rhapsody in Two Languages was perhaps the most well-known, but it's fascinating to see "Music from the Stars" presenting a young Horace Lapp and his orchestra. Horace also lived to a ripe old age, and for many years provided the piano accompaniment for silent movies presented by Toronto Film Society and the Ontario Film Theatre. (As an aside, he used to upset the purists by playing "Smoke Gets in Your Eyes" every time a screen character lighted a cigarette...)

Scripts were, for the period, intelligent and humorous and even poetic, and the black-and-white photography sparkled. Glimpses of "Shadow River", "Hockey Champions", "Ballet of the Mermaids" with swimming in patterns and tinted green (reminders of Esther Williams!), and John Pratt enduring the trials of skiing in Sitzmark on the Spot."

In this documentary, Gordon Sparling emerges as a quiet, modest and understated man who knew his job and did it excellently well. "I tried to do the best I could. I didn't waste time on regrets, but tried to do better the next time."

He adds quietly that "it was always in the back of my mind to make a full-length film". But it never came about -- more's the pity.

(2) STORIES FROM THE LAND OF CAIN

Producer, Director, Camera: Mark Wihak.

Music, Rheostatics.

Canada 1995, 25 min.

"I grew up in a pink house on the west side of Regina.

I live in a double room in the Mile End of Montreal."

A wander by car across the country from a western city to an eastern city; a drift through the filmmaker's memories at the time of Meech Lake and the Oka crisis; reflections on the Metis struggle for independence at Batoche and arriving on the Plains of Abraham in Québec. The road runs through cities, small towns, the countryside, and where it stops, people reminisce -- about going away, about coming back to home and appreciating it. The car passengers discuss points of history, dredge up recollections and stories as they bowl along. Present-day intermingles with material from the past, intercutting, voices overlapping and fading in and out, French and English intertwining.

A kind of stream-of-consciousness ramble which is obviously very personal to its maker, and just the sort of thing which many find irritating. Not a neat, tidy film by any means, and its shapelessness leads one to ponder on the direction of the filmmaker's career... 
(3) YOUR NAME IS CELLULITE

Animator: Gail Noonan.

Music and foley sound effects: Ian Mackie.

Canada 1995, 6 min.

Blast off...with a lipstick, a vicious metal eyelash curler and all the accoutrements of modern "beauty" aids. With an eagle eye, animator Gail Noonan skewers the madness of makeup and the body beautiful. All the tortures are mercilessly exposed and visions of bolstered bosoms, pumped-up lips, ruthless hair removal and bizarre hair styling are accompanied by driving music and a teeth-rattling soundtrack. Commonsense finally triumphs in this bright and satirical set-down, which has won several well-deserved awards.

\section{Author Information}

Patricia THOMPSON (d. 1999) was Publisher and Editor of Film Canada Yearbook and Canadian Editor for the International Motion Picture Almanac and the International Television and Video Almanac (Quigley, NY). She was reviewing Canadian short films for several decades. 